\title{
Coupling Mineralogical Analyses, Leaching Tests and Kinetic Modelling to Unravel Groundwater Flow-Paths in a Complex Landslide: An Attempt from the Vedriano Case Study (Northern Italian Apennines)
}

\author{
Federico Cervi $^{1, *,+(\mathbb{D})}$ and Alberto Tazioli ${ }^{2}$ (D) \\ 1 Department of Civil, Chemical, Environmental and Materials Engineering, University of Bologna, \\ 40136 Bologna, Italy \\ 2 Dipartimento di Scienze e Ingegneria della Materia, dell'Ambiente ed Urbanistica, Università Politecnica \\ delle Marche, 60131 Ancona, Italy; a.tazioli@staff.univpm.it \\ * Correspondence: fd.cervi@gmail.com \\ † Current address: Hydrogeologist, 42122 Reggio Emilia, Italy.
}

Citation: Cervi, F.; Tazioli, A. Coupling Mineralogical Analyses, Leaching Tests and Kinetic Modelling to Unravel Groundwater Flow-Paths in a Complex Landslide: An Attempt from the Vedriano Case Study (Northern Italian Apennines). Geosciences 2021, 11, 1. https://dx.doi.org/10.3390/ geosciences 11010001

Received: 20 November 2020 Accepted: 15 December 2020 Published: 22 December 2020

Publisher's Note: MDPI stays neutral with regard to jurisdictional claims in published maps and institutional affiliations.

Copyright: $\odot 2020$ by the authors. Licensee MDPI, Basel, Switzerland. This article is an open access article distributed under the terms and conditions of the Creative Commons Attribution (CC BY) license (https:/ / creativecommons.org/ licenses/by/4.0/).

\begin{abstract}
As the rise in pore water pressure is one of the main factors in triggering landslides, the understanding of groundwater processes taking place at the hillslope scale is a crucial issue in slope stability analysis. However, identifying flow-paths travelled by water molecules from their infiltration is still a complex task. Hydrochemistry is recognized as a powerful tool that can help to gain useful hydrogeological information and has gradually become increasingly used in addition to conventional study methods. This manuscript presents a comprehensive geochemical investigation consisting of leaching tests and quantitative mineralogical analyses on soil samples, chemical analyses on groundwater samples and modelling. Our results highlighted the usefulness of coupling, even in hydrogeological studies focusing on landslides, geochemical surveys on both water and the soil matrix to constrain the interactions between host-rocks and groundwater. Moreover, it demonstrated that kinetic-based geochemical models, if properly calibrated on leaching tests, can provide valuable information on groundwater dynamics, allowing us to elucidate water-mixing processes beneath the soil surface.
\end{abstract}

Keywords: geochemical modelling; hydrochemistry; leaching tests; mineralogical analyses; clayshales; landslide; northern Apennines

\section{Introduction}

The chemical composition of groundwater represents a signature of the hydrogeological processes taking place beneath the soil surface. Within the slopes, it is the result of the interaction between infiltrating water and subsurface soil (vadose zone) and subsequently groundwater and host soils and rocks (saturated zone). Water chemistry can provide a wide range of information on the origin, aquifer (or aquitards or aquicludes) characteristics and flow-paths. The study of water chemistry (hydrochemistry) has for a long time been widely used in catchment hydrology as a tool to identify the different components making up the run-off [1,2]. In hydrogeological studies involving landslides, hydrochemistry has recently started to be applied. In their review, [3] underlined the efficacy of hydrochemical techniques both for hard-rock slopes (fractured and fissured materials) and unconsolidated sediments like marls and clays. The same authors took the examples of several cases from the French Alps, in which hydrogeochemical features provided evidence of external recharge areas (Super Sauze landslide, [4]), water reservoir characteristics (La Clapiere landslide, [5]), chemical changes related to mechanical stresses (Le Séchilienne landslide, [6] and La Clapiere landslide, [7]). Among the several hydrochemical investigations, hydrogeochemical modelling allows us to make headway in the understanding of 
hydrogeological processes in clayey geological units. By simulating the dissolution and precipitation of mineralogical phases composing the slope, it provides an explanation for groundwater chemical changes taking place beneath the soil surface. Guglielmi et al. [8] provided a first exercise on hydrochemical modelling in order to explain peculiar amounts of sulphate in the groundwater hosted in the landslide body of the La Clapiere slope (French Alps). Deiana et al. [9] used inverse modelling to identify which mineralogical phases (and in what quantities) had to be dissolved to provide the observed chemistry of water flow-paths in the Berceto landslide (northern Italian Apennines). By modelling the interaction between the observed mineralogical bulk and rainwater, Cervi et al. [10] demonstrated the mixing between rainfall recharge and deep water rising up from the bottom in $\mathrm{Ca}^{\prime}$ Lita unstable slope (northern Italian Apennines).

All the above-mentioned studies have exploited thermodynamic modelling. The latter consists of equilibrium-based models that take into account the long-term chemical interaction between pore water solutions and host rocks, in which the irreversible dissolution of reactants and the reversible precipitation of secondary products may occur. It must be recalled that chemical equilibrium normally requires very long times that, because the rates of many chemical reactions are slow, may develop even on a geological time scale. Hydrochemical processes occurring at the slope scale usually proceed extremely rapidly (within a few years in the majority of cases) and the bulk mass of the groundwater often remains undersaturated with respect to minerals that occur in the solid media. In this sense, a kinetic approach (i.e., an approach that represents non-equilibrium reactions, for which a rate expression can be formulated) would be more representative of the hydrological processes that occur on a slope scale. Unlike the thermodynamic approach, such models incorporate the time factor into their mathematical expression.

To the best of our knowledge, to date the only study that has adopted kinetic modelling for the hydrogeology of landslides is the one described in [11]; they carried out kineticbased models for unravelling the different flow-paths feeding the groundwater within a complex landslide in the French Alps (Super Sauze landslide).

The present work deals with a comprehensive approach coupling leaching tests, mineralogical analyses and geochemical modelling. The approach has been developed for a clay-rich landslide from the northern Italian Apennines and located in a geologicallycomplex-area in which several clay-rich geological formations have been superimposed. Moreover, a kinetic-approach has been tested in order to explain the hydrochemical evolution of the groundwater in the upper part of the landslide and the results are compared with the chemical signatures of the available groundwater monitoring points.

Modelling efforts are focused to simulate the interaction between meteoric recharge and solid matrix (made up of both disrupted rocks and weathered soils) that usually takes place in late summer-early autumn (i.e., the end of the low-flow period in the northern Italian Apennines), when meteoric water infiltrates towards the main soil slip surface through open cracks and fissures, inducing quick rises in pore pressures and subsequent potential reactivation of landslides [12-14].

\section{Study Site}

The Vedriano landslide (in the literature the term "Lavina di Roncovetro" is also used) is an active earth-flow located in the northern Italian Apennines (Reggio Emilia Province; lat. $44^{\circ} 30^{\prime} 00^{\prime \prime} \mathrm{N}$; long. $10^{\circ} 23^{\prime} 18^{\prime \prime} \mathrm{E}$ ).

From a climatic point of view, and following [15], the site is characterised by a mean annual rainfall distribution over the 1990-2015 period close to $1100 \mathrm{~mm} / \mathrm{y}$. The rainfall pattern during the year usually shows two marked positive peaks in the autumn and spring seasons, when cumulative amounts may account for 550 and $630 \mathrm{~mm}$, respectively (in the summer months precipitations are reduced as well as during the winter months). Moreover, potential evapotranspiration is particularly active during the summer period, when it reaches cumulative values of up to $470 \mathrm{~mm}$. 
Following the geomorphological map reported in [16] (see Figure 1), the landslide body can be divided into four different sectors, namely: earthslide or source area, earthflow 1 or upper track zone, earthflow 2 or upper track zone and deposition area or toe zone. The crown of the earthslide (Figure 1) affects the main peak of the watershed divide (Mt. Staffola, $690 \mathrm{~m}$ a.s.l) while the toe flanks the Tassobbio River ( $310 \mathrm{~m}$ a.s.l.). The total length is $2.5 \mathrm{~km}$ with a maximum depth of about $20 \mathrm{~m}$. The first news of the landslide allows us to date it to 1907. The movement is characterised by paroxysmal phases (in which the maximum velocities can be on the order of $10 \mathrm{~m}$ per day in the source area and $100 \mathrm{~m}$ per day in the upper track zone) that alternate with dormant or suspended phases, in which displacements are lower than a few dozen $\mathrm{cm}$ per year (see [16,17]).
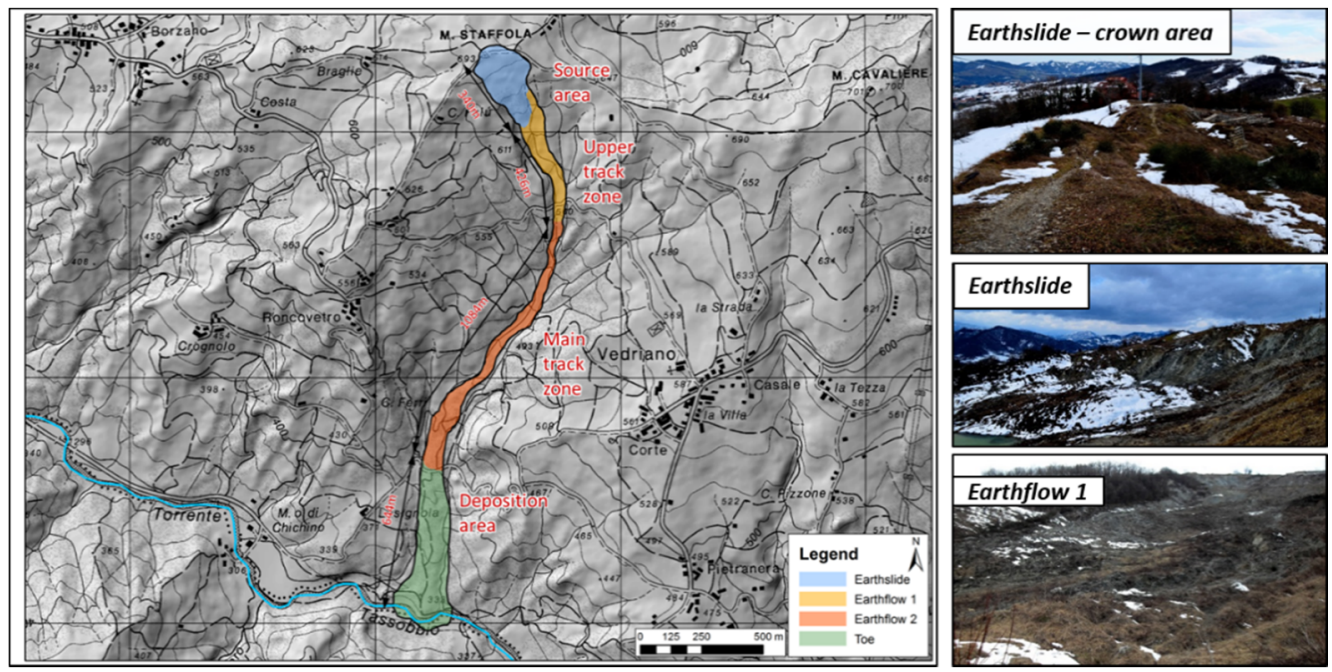

Figure 1. On the left, the Vedriano landslide with the four different sectors (namely: source area or earthslide, upper track zone or earthflow1, main track zone or earthslide2 and deposition area or toe zone). On the right, photos taken in winter 2013 from the source area and earthflow 1.

Main reactivations took place in 1936 and 1993. Starting from 1993, the landslide had to be considered as active, and a cumulative displacement of about $100 \mathrm{~m}$ per year was detected. The landslide (see Figure 2) involved a hillslope composed of formations belonging to the Sub-Ligurian Units (MSF2: "Formazione di Monte Staffola-Membro di Borzano", MSF3: "Formazione di Monte Staffola-Membro di Vedriano", MSF3a: "Formazione di Monte Staffola-Membro di Vedriano-litofacies marnosa", and MSF3b: "Formazione di Monte Staffola-Membro di Vedriano-litofacies argillitica") which outcrop in a tectonicwindow structure, i.e., surrounded by Ligurian Units (APA: "Argille a Palombini"). In all the cases, formations mainly consist of marls and clays [18]. In particular Bertolini et al. [16] highlighted the presence of thick white crusts that cover large areas in the vicinity of the crown zone during the summer period and re-dissolve during the winter and spring periods (Figure 3).

A groundwater monitoring network was installed in the earthslide zone about fifteen years ago and is still in operation. It consists of an open-pipe piezometer (P1, see Figure 3) upstream to the earthslide (i.e., the crown where open cracks and fissures identify the detachment of the landslide from Mt. Staffola) in which the groundwater level closely follows the meteoric recharge pattern of the site (between 4.2 and $1.5 \mathrm{~m}$ below the surface). Inside another piezometer (P2, Figure 3), drilled three hundred meters downslope (where the main slip surface of the earthslide crosses the soil surface allowing the development of earthflow1), the groundwater is currently at about $3 \mathrm{~m}$ depth. In addition, in the earthslide, two springs (S1 and S2 in Figure 3) continuously discharge a few litres per minute. 


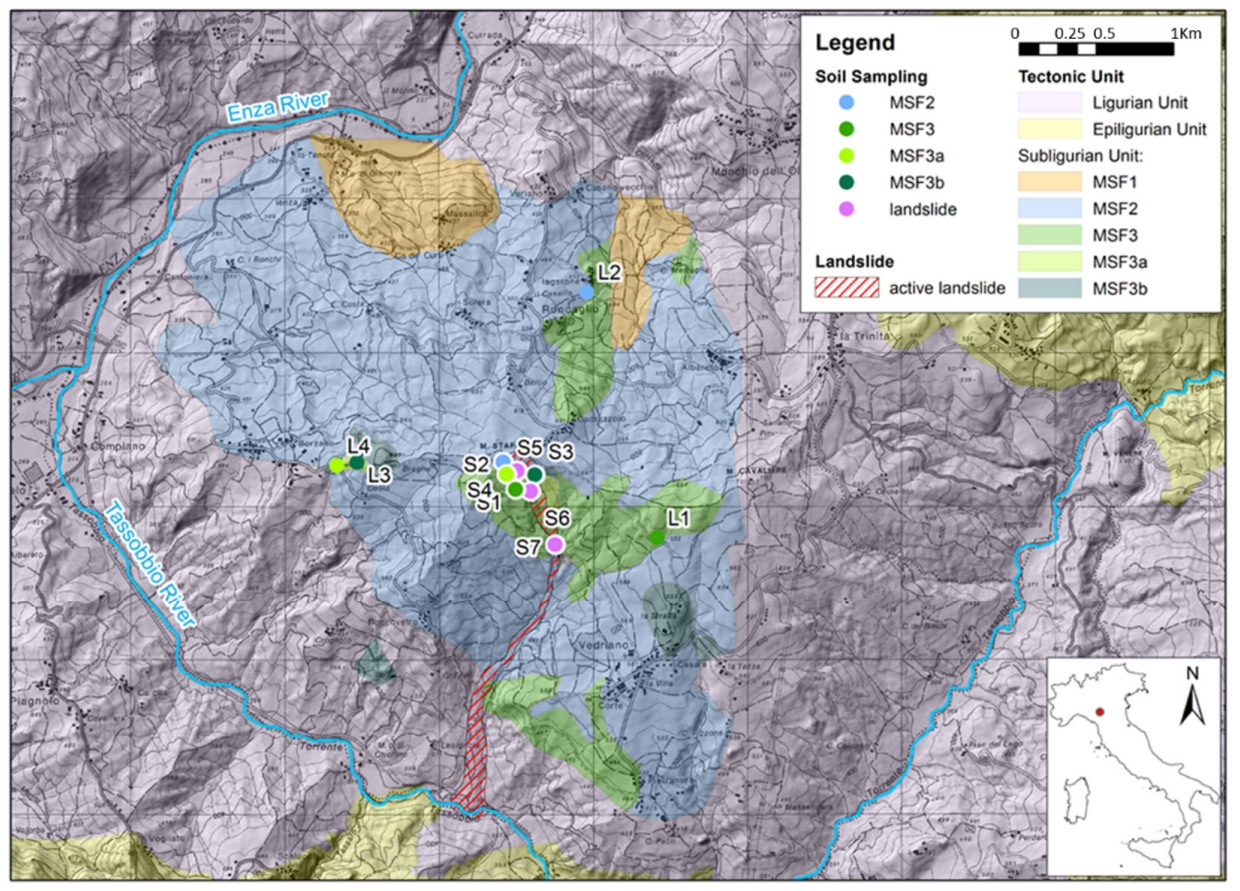

Figure 2. Schematic map of the geological unit (Subligurian and Ligurian units) outcropping in the Vedriano landslide area along with the locations in which soil samples for further leaching and mineralogical tests were collected (in the vicinity of the landslide: S1 to S7; outcrops located $2 \mathrm{~km}$ far from the landslide:L1 to L4).

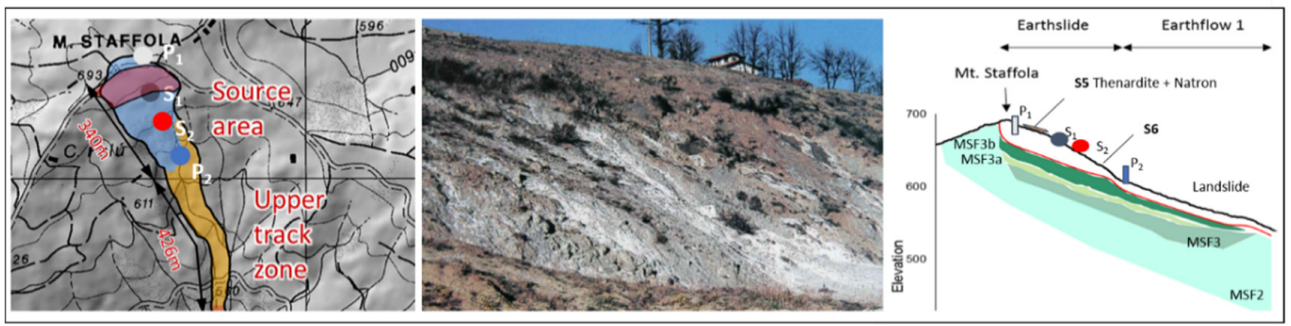

Figure 3. On the right, detail of the groundwater monitoring points in the source and earthslide1 zones (S1 and S2: springs; P1 and P2: piezometers) together with the area in which the thick white crusts (in purple) outcrop. In the middle, a photo taken in August 2015 in which the white powder is clearly visible together with the spring S2. Simplified geological cross section of the source and earthslide1 zone along with the groundwater monitoring points (P1, P2, S1, and S2) and soil samples S5 and S6.

\section{Methodology}

The methodology applied in this study is represented in the form of a flowchart in Figure 4. Fieldwork was carried out between July 2015 and September 2015 (a period in which no effective precipitation occurred, i.e., no recharge of the groundwater was possible) and consisted of both groundwater and soil sampling activities. More specifically, water samples were collected to estimate the chemical contents of groundwater characterising the landslide area. Soils samples were collected from several outcrops from the source area of the landslide or in its vicinity; the samples are representative of all the geological formations outcropping near the Mt. Staffola. Soil samples were used for carrying out leaching experiments, grain size distributions tests and mineralogical analyses. Grain size distributions and mineralogical analysis allowed us to develop kinetic-based hydrochemical models whose calibrations were constrained with the results of leaching experiments. Finally, once the kinetic parameters were calibrated, kinetic runs were carried out in order 
to simulate the long-term chemical interactions between the rainfall water and host rocks (earthslide) in the source area of the landslide.

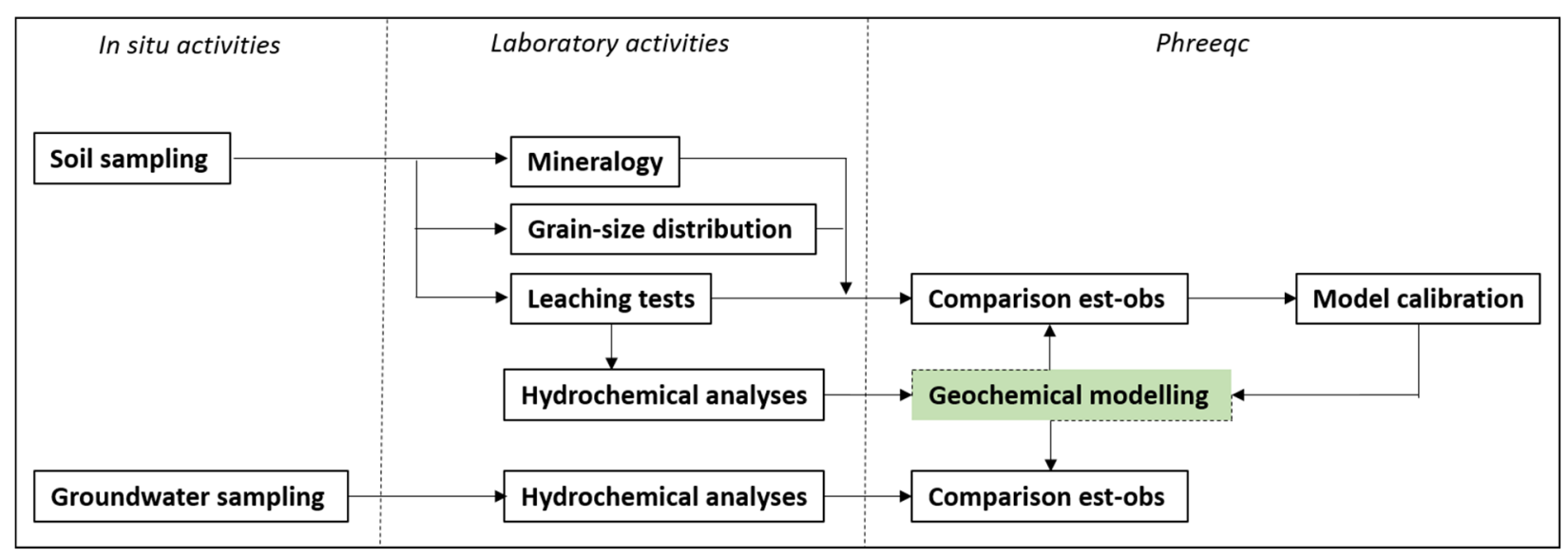

Figure 4. Flowchart of the methodology used in this work (modified after [11]).

\subsection{Groundwater Sampling and Laboratory Analyses}

Groundwater was sampled after low-flow purging and stabilization of the physicalchemical parameters, namely: temperature $\left(\mathrm{t},{ }^{\circ} \mathrm{C}\right)$, electrical conductivity $\left(\mathrm{EC} ; \mathrm{us} \mathrm{cm}^{-1}\right)$, acid potential $(\mathrm{pH})$ and redox potential $(\mathrm{Eh})$. The latter were measured by means of a Crison MM40+ multimeter equipped with a Ross glass electrode for $\mathrm{pH}$. Depending on the instrument, precisions were $\pm 0.5-2 \%(\mathrm{EC}), \pm 0.2-0.5^{\circ} \mathrm{C}(\mathrm{t})$ and $\pm 0.01-0.05(\mathrm{pH})$. Water samples for laboratory analyses were collected in glass bottles after filtration through $0.45 \mu \mathrm{m}$ cellulose membranes, and the aliquot for cation analysis was further acidified with $65 \% \mathrm{HNO}_{3}$ Suprapur Merck.

Major elements $\left(\mathrm{Ca}^{2+}, \mathrm{Na}^{+}, \mathrm{Mg}^{2+}, \mathrm{SO}_{4}{ }^{2-}\right.$, and $\left.\mathrm{Cl}^{-}\right)$have been analysed by means of ion chromatography on 28 groundwater samples coming from 2 low-yield springs (S1 and $\mathrm{S}_{2}$ ) and 2 piezometers $\mathrm{P} 1$ and P2 (7 samples from each groundwater monitoring point with fortnightly sampling activities; see Figure 3). $\mathrm{HCO}^{3-}$ was determined by Gran titration [19] not later than $24 \mathrm{~h}$ after sampling.

\subsection{Soil Sampling and Laboratory Analyses}

A total of 77 soil samples were collected for leaching experiments at depths between $0.5 \mathrm{~m}$ and $1 \mathrm{~m}$ (see Figure 2). More specifically, 56 soil samples representative of the geological units MSF3, MSF2, MSF3b and MSF3a were collected near the Mt. Staffola peak (i.e., in the vicinity of the landslide area; in this case samples were labelled as follows: S1(MSF3), S2 (MSF2), S3 (MSF3b) and S4 (MSF3a)) or from outcrops located $2 \mathrm{~km}$ far from the landslide area (samples were labelled as L1 (MSF3), L2(MSF2), L3(MSF3b) and L4(MSF3a). Another 21 samples were collected within 2 sectors of the landslide, namely: source area (S5) and earthflow1 (S6 and S7). In short, for every geological unit, 7 leaching tests were carried out and data for each sample were presented as mean values together with standard deviation $(1 \sigma)$.

In detail, each leaching test was carried out according to the USGS field leach test procedures [20]. In detail, $50 \mathrm{~g}$ of dried material for each sample was sieved to less than $2 \mathrm{~mm}$ and leached into 11 of deionized water, continuously shaken by a magnetic stirrer (with a constant rotation speed of $200 \mathrm{rpm}$ ). The experiments stretched over a maximum of $10 \mathrm{~h}$, while an electrical conductivity probe was used to monitor water mineralisation on a fixed timetable ( $30 \mathrm{~s}, 1 \mathrm{~min}, 2 \mathrm{~min}, 5 \mathrm{~min}, 10 \mathrm{~min}, 30 \mathrm{~min}, 1 \mathrm{~h}, 6 \mathrm{~h}$, and $10 \mathrm{~h}$ ). Water samples were collected to determine the major ion contents following the same procedure reported in Chap. 3.1 (for a total of 77 samples); one such test was carried out for every 7 leaching tests and one such test was carried out for each time step. 
Aliquots from the abovementioned seven soil samples S1, S2, S3, S4, S5, S6, and S7 were kept prior to leaching for further grain size distribution and mineralogical analyses. In particular, bulk and clay mineralogy on a $<2 \mu \mathrm{m}$ fraction were measured by X-ray diffractometry on oriented paste and coupled with the [21] approach. A further mineralogical analysis was performed on a sample composed of a fine white powder collected in the earthslide, where the S5 were also sampled.

\subsection{Hydrochemical Modelling}

\subsubsection{Model Formulation}

Hydrochemical modelling was carried out exploiting the Phreeqc software [22]. The latter can simulate the water-rock interaction by the dissolution of the primary minerals and the precipitations of a new phase over time (kinetic approach). For each time step, the quantity of destroyed or formed phases per $\mathrm{kg}$ of water was calculated, according to the mineral assemblage and the kinetic parameters of each phase. Among the several equations describing the dissolution and precipitation of minerals in a solution, the formulation from reference [23] is the most used in literature. It can be used for both acid, neutral and basic solutions and is written as follows:

$$
\frac{d[M]}{d_{t}}=K_{m} S_{m} a_{H+}^{n} 1-\frac{Q}{K}
$$

where $d[M] / d t$ is the dissolution rate $\left(\mathrm{mols}^{-1}\right), K_{m}$ is the kinetic constant for each mineral (mol cm ${ }^{-1} \mathrm{~s}^{-1}$, in which three different values $\mathrm{K}_{m}{ }^{H}, K_{m}{ }^{\mathrm{H} 2 \mathrm{O}}$ and $\mathrm{K}_{m}{ }^{\mathrm{OH}}$ have to be considered for the basic, neutral and acid environment, respectively), $\mathrm{aH}^{+}$is the proton activity in the solution, $\mathrm{n}$ is the reaction order, and $S_{m}$ is the mineral reactive surface $\left(\mathrm{m}^{2}\right)$.

The ratio $(1-Q / K)$ represents the thermodynamic drive for the reaction through the saturation index $(Q / K)$ where $Q$ is the activity product and $K$ is the equilibrium constant: when the mineral is supersaturated, $Q>K$ and the mineral precipitates. When it is undersaturated, $Q<K$ and the mineral dissolves.

It must be highlighted that the dissolution rate $d[M] / d t$ depends on temperature by the Arrhenius law:

$$
\frac{d[M]}{d_{t}}=A_{m} \exp \frac{-E_{a, M}}{R T}
$$

with $A_{m}$ representing the frequency factor, $E_{a, M}$ the activation energy of mineral dissolution reaction $\left(\mathrm{J} \mathrm{mol}^{-1}\right), R$ is a gas constant (equal to $8.31 \mathrm{~J} \mathrm{~mol}^{-1} \mathrm{~K}^{-1}$ ) and $T$ is the water temperature $(\mathrm{K})$.

\subsubsection{Data Inputs}

The required inputs for the model are: the initial bulk (M) of the sample, the kinetic constants $\left(K_{m}{ }^{H}, K_{m}{ }^{H 2 O}\right.$ and $\left.K_{m}{ }^{O H}\right)$ and the corresponding specific surface $\left(S_{m}\right)$ of each mineral composing the bulk together with its reaction order (n). To calculate the amount of phases (in moles) which have interacted with the rock through the pores, the porosity of the soil sample is required; in our case we follow the procedure reported in [24] with the estimation of the porosity starting from the grain size distribution. The mineral reactive surface $S_{m}$ is further estimated by considering each grain as a sphere:

$$
S_{m}=\frac{S p_{m} M_{0} P M}{10,000}
$$

In which $M_{0}$ and $P M$ are the moles and the molecular weight of the mineral within the bulk, respectively. $S p_{m}$ (in $\mathrm{cm}^{2} \mathrm{~g}^{-1}$ ) is the specific surface per gram of the sphere that can be obtained with:

$$
S p_{m}=\frac{6}{\sigma d}
$$


where $\sigma$ is the specific density of the mineral $\left(\mathrm{g} \mathrm{cm}^{-3}\right)$ and $d(\mathrm{~cm})$ is the diameter of the sphere. In case of phyllosilicatic minerals (i.e., minerals with shape not assimilable to that of the sphere), and $S p_{m}$ came from [25]. The kinetic rate constant $\mathrm{Km}$ of each mineral and the reaction orders $n$ were extracted from the literature $[26,27]$. It must be highlighted that, due to the large variability of the shape data of the soil grains, it is commonly suggested to calibrate the $S p_{m}$ data with the results of the leaching test (see [11]). In particular, the calibration has to be carried out by comparing observed and simulated main ions $\left(\mathrm{Na}^{+}\right.$, $\mathrm{Ca}^{2+}, \mathrm{K}^{+}, \mathrm{Mg}^{2+}, \mathrm{SO}_{4}{ }^{2-}, \mathrm{HCO}_{3}{ }^{-}$, and $\mathrm{Cl}^{-}$) observed in the water samples collected during leaching tests.

\section{Results}

\subsection{Groundwater Chemistry}

Results of the fortnightly sampling campaigns lasting between July 2015 and September 2015 (for a total of 7 campaigns) are summarised in Table 1 as maximum and minimum values for both physical-chemical parameters $(\mathrm{pH}$, electrical conductivity EC, temperature, Eh) and main chemicals $\left(\mathrm{Na}^{+}, \mathrm{Ca}^{2+}, \mathrm{K}^{+}, \mathrm{Mg}^{2+}, \mathrm{SO}^{2-}, \mathrm{HCO}_{3}{ }^{-}\right.$, and $\left.\mathrm{Cl}^{-}\right)$from the groundwater monitoring points ( $\mathrm{P} 1, \mathrm{P} 2, \mathrm{~S} 1$, and $\mathrm{S} 2)$.

In all the points, groundwater showed an increase of EC (as well as temperature) from July 2015 to September 2015 in all 4 monitoring points. Piezometers showed the lowest values of EC $\left(1620 \mu \mathrm{s} \mathrm{cm}^{-1}\right.$ of P1) while springs S2 was characterised by remarkably high mineralization (EC up to $4830 \mu \mathrm{s} \mathrm{cm}^{-1}$ ). Temperatures ranged from $13.2^{\circ} \mathrm{C}(\mathrm{P} 1)$ to $15.9^{\circ} \mathrm{C}$ (S1) while $\mathrm{pH}$ values were always close to neutral with the exception of the 2 samples from $\mathrm{P} 1$, which were slightly acidic ( $\mathrm{pH}=6.80$ for the first two samples collected in July 2015). Redox potential Eh was constant over time and indicated oxidizing conditions for all groundwater; some discrepancies were noticed as Eh values were similar for P2 and S1 (about $+68 \mathrm{mV}$ ) while the highest values were detected in P1 $(+98 \mathrm{mV}$, indicating that this groundwater was exposed to the atmospheric oxygen more recently that the others). The lowest values of Eh were found in $\mathrm{S} 2(+18 \mathrm{mV})$.

From the chemical point of view, all groundwater contained $\mathrm{Na}-\mathrm{SO}_{4}\left(\mathrm{Na}^{+}\right.$from 262 to $1160 \mathrm{mg} \mathrm{L}^{-1}$ and $\mathrm{SO}_{4}{ }^{2-}$ between 460 and $1430 \mathrm{mg} \mathrm{L}^{-1}$ ) with a non-negligible amount of $\mathrm{HCO}_{3}{ }^{-}$(420 to $960 \mathrm{mg} \mathrm{L}^{-1}$ ). $\mathrm{Mg}^{2+}$ and $\mathrm{K}^{+}$were always about 50 and $3 \mathrm{mg} \mathrm{L}^{-1}$, respectively. $\mathrm{Cl}^{-}$ranged between 24 to $50 \mathrm{mg} \mathrm{L}^{-1}$ while $\mathrm{Ca}^{2+}$ was between 40 and $48 \mathrm{mg} \mathrm{L}^{-1}$.

\subsection{Leaching Tests}

Results of the leaching tests were summarised in Figure 5 (as mean values with standard deviations $1 \sigma$; all data were also provided in the form of Supplementary Materials). In all the cases, the time required to reach the final concentration was generally short: at least $70 \%$ of the total chemical content was achieved within $10 \mathrm{~min}$, and $90 \%$ within $1 \mathrm{~h}$. Clearly, the $1 \mathrm{~h}$ samples are already representative of the lixiviation interactions between soil and water. At the end of the test (here we recall that tests lasted for $10 \mathrm{~h}$ ), the lower EC was detected in soil samples L1 and L3.

Remarkably high values were detected in some samples from the landslide area, namely S3, S4 and S5. The latter showed the highest value, having its mean EC close to $280 \mu \mathrm{s} \mathrm{cm}^{-1}$ while S3 and S5 were close to $100 \mu \mathrm{s} \mathrm{cm}-1$. By verifying the chemical analysis carried out on the samples collected at $1 \mathrm{~h}$ of leaching, water from $\mathrm{S} 5$ showed an enrichment of $\mathrm{Na}^{+}\left(70 \mathrm{mg} \mathrm{L}^{-1}\right), \mathrm{SO}_{4}{ }^{2-}\left(86 \mathrm{mg} \mathrm{L}^{-1}\right)$ and $\mathrm{HCO}_{3}{ }^{-}\left(77 \mathrm{mg} \mathrm{L}^{-1}\right)$ with respect to all the other samples. In fact, all the other 6 samples were mainly calcium-bicarbonate, having $\mathrm{Ca}^{2+}$ values between 0.1 and $7 \mathrm{mg} \mathrm{L}^{-1}$, while $\mathrm{HCO}_{3}{ }^{-}$was in the range of 5 to $36 \mathrm{mg} \mathrm{L}^{-1}$. 


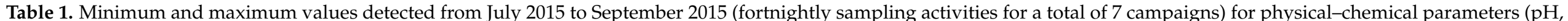

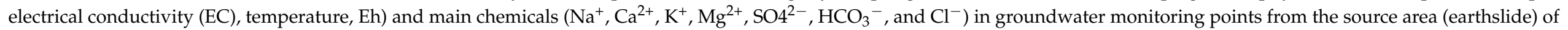
the Vedriano landslide.

\begin{tabular}{|c|c|c|c|c|c|c|c|c|c|c|c|}
\hline $\begin{array}{c}\text { Groundwater } \\
\text { Monitoring Point }\end{array}$ & $\mathrm{pH}$ & $\begin{array}{c}\text { Cond } \\
\left(\mu \mathrm{sm}^{-1}\right)\end{array}$ & $\mathrm{t}\left({ }^{\circ} \mathrm{C}\right)$ & Eh $(\mathrm{mV})$ & $\begin{array}{c}\mathrm{Na}^{+} \\
\left(\mathrm{mg} \mathrm{L}^{-1}\right)\end{array}$ & $\begin{array}{c}\mathrm{Ca}^{2+} \\
\left(\mathrm{mg} \mathrm{L}^{-1}\right)\end{array}$ & $\begin{array}{c}\mathrm{K}^{+} \\
\left(\mathrm{mg} \mathrm{L}^{-1}\right)\end{array}$ & $\begin{array}{c}\mathrm{Mg}^{2+} \\
\left(\mathrm{mg} \mathrm{L}^{-1}\right)\end{array}$ & $\begin{array}{c}\mathrm{SO}_{4}^{2-} \\
\left(\mathrm{mg} \mathrm{L}^{-1}\right)\end{array}$ & $\begin{array}{l}\mathrm{HCO}^{-} \\
\left(\mathrm{mg} \mathrm{L}^{-1}\right)\end{array}$ & $\begin{array}{c}\mathrm{Cl}^{-} \\
\left(\mathrm{mg} \mathrm{L}^{-1}\right)\end{array}$ \\
\hline $\mathrm{P} 1$ & $6.80-7.10$ & $1620-1790$ & $13.2-14.7$ & +98 & $206-288$ & $42-48$ & $41-43$ & 2 & $390-470$ & $430-500$ & $24-26$ \\
\hline P2 & $7.22-7.36$ & 2445-2876 & $13.9-14.2$ & +69 & $780-878$ & $40-42$ & $43-47$ & $2-3$ & $698-876$ & $610-690$ & $31-38$ \\
\hline $\mathrm{S} 1$ & 7.10-7.19 & 2750-2983 & $14.5-15.9$ & +67 & $698-736$ & $45-47$ & $48-50$ & $2-3$ & 1298-1401 & $370-460$ & $44-46$ \\
\hline S2 & $7.12-7.24$ & $3980-4830$ & $14.3-15.8$ & +18 & 890-1098 & $46-47$ & $46-50$ & 3 & $1415-1440$ & $860-960$ & $33-50$ \\
\hline
\end{tabular}




\subsection{Soil Analyses}

Results from the grain size distributions and mineralogical analyses are reported in Tables 2 and 3, respectively. All the samples were mainly composed of silt (from $57.0 \%$ to $75.2 \%$ ), followed by clay (between $14.2 \%$ to $22.7 \%$ ) and sand (from $8.5 \%$ to $31.9 \%$ ). From the mineralogical point of view, the results showed that samples from the landslide (S5, S6, and S7 in Table 2) were almost similar despite a certain difference emerging in the plagioclase content (albite that is absent in $\mathrm{S} 6$ while at $11.4 \%$ in S4). Landslide samples showed compositional affinity with S1 (MSF3), S2 (MSF2) and S4 (MSF3a), while some discrepancies have been detected with S3 (MSF3b) as this sample was characterised by the presence of kaolinite and smectite that were not present within samples collected in the landslide). It should be added that the mineralogical analyses carried out on the sample further from the landslide was composed of a fine white powder collected from the crown area of the landslide (in the vicinity of S5) and was made up of thenardite $\left(\mathrm{Na}_{2} \mathrm{SO}_{4}\right)$ and natron $\left(\mathrm{Na}_{2} \mathrm{CO}_{3} \cdot 7 \mathrm{H}_{2} \mathrm{O}\right)$. If we consider the leaching test carried out on $\mathrm{S} 5$, the presence of mineralogical phases containing sulphate that were not identified by the mineralogical analyses can be evidenced (see the absence of phases containing sulphur in Table 2); in particular, the ratio $\left(\mathrm{Na}^{+}\right) /\left(\mathrm{SO}_{4}{ }^{2-}+\mathrm{HCO}_{3}{ }^{-}\right)$in meq $\mathrm{L}^{-1}$ is always close to 1 in the leached water from S5, suggesting the dissolution of natron and thenardite that, at the end of the leaching $(10 \mathrm{~h})$ could be quantified in about 0.28 and $0.06 \mathrm{~g}$, respectively.

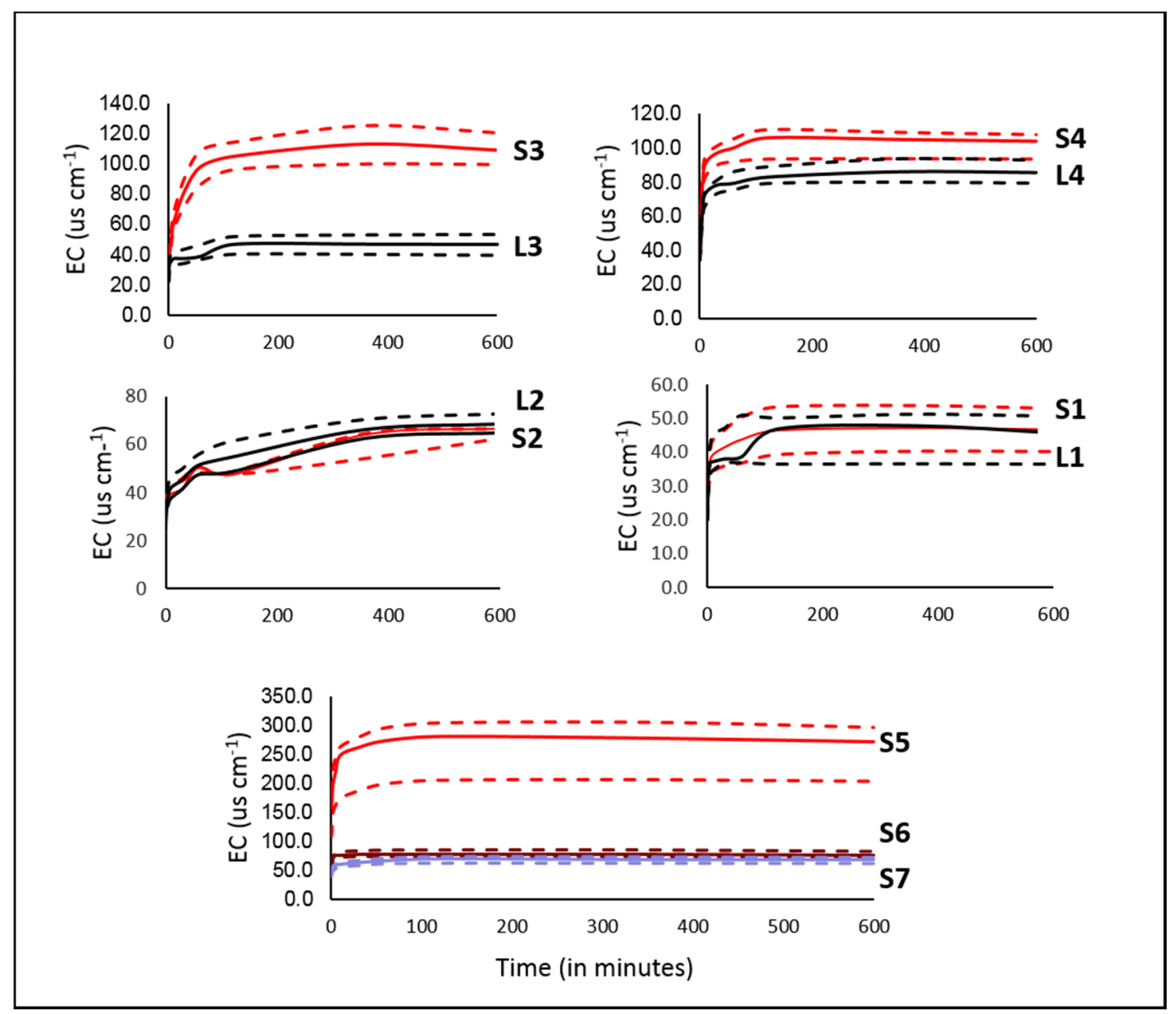

Figure 5. Result of the leaching test (electrical conductivity (EC) values) carried out on soil samples shown in Figure 2 from L1 to L4 (in dark) and S1 to S7 (from red to purple), presented as mean values (continuous line) together with standard deviations (as $1 \sigma$; dashed lines). 


\subsection{Modelling}

As reported in Section 3.3.2 (data inputs), the kinetic simulation involving the mineralogical assemblages of S5 (Table 4) started with the calibration of specific surface $S p_{m}$ parameter. The calibration has to be carried out by comparing observed and simulated main ions $\left(\mathrm{Na}^{+}, \mathrm{Ca}^{2+}, \mathrm{K}^{+}, \mathrm{Mg}^{2+}, \mathrm{SO}_{4}{ }^{2-}, \mathrm{HCO}_{3}{ }^{-}\right.$, and $\left.\mathrm{Cl}^{-}\right)$observed in the water samples collected after each step of the leaching tests. In this model, we did not consider porosity, as the soil sample was supposed to interact completely with the water. Moreover, water is allowed to exchange $\mathrm{O}_{2}$ and $\mathrm{CO}_{2}$ with the atmosphere (i.e., $\operatorname{logpCO}(\mathrm{g})=-3.5$ and $\left.\log \mathrm{O}_{2}(\mathrm{~g})=-0.68\right)$ and no secondary phase precipitations were allowed. For the sake of convenience, in Figure 6 we reported the observed and estimated (only that from the best calibration) $\mathrm{Na}^{+}, \mathrm{SO}_{4}{ }^{2-}$ and $\mathrm{HCO}_{3}{ }^{-}$during the leaching tests, as they were related to the thenardite $\left(\mathrm{Na}_{2} \mathrm{SO}_{4}\right)$ and natron $\left(\mathrm{Na}_{2} \mathrm{CO}_{3} \cdot 7 \mathrm{H}_{2} \mathrm{O}\right)$ dissolution.

Table 2. Grain size distribution results of the seven samples (S1, S2, S3, S4, S5, S6, and S7) in the form of sand, silt and clay are reported as \% in weight.

\begin{tabular}{ccccc}
\hline $\begin{array}{c}\text { Sample } \\
\text { Code }\end{array}$ & $\begin{array}{c}\text { Referring Geological Formation } \\
\text { (or Landslide Area) }\end{array}$ & Sand (\%) & Silt (\%) & Clay (\%) \\
\hline S1 & MSF3 & 13.9 & 64.8 & 21.2 \\
\hline S2 & MSF2 & 31.9 & 57.0 & 11.1 \\
\hline S3 & MSF3b & 8.5 & 68.8 & 22.7 \\
\hline S4 & MSF3a & 23.1 & 60.4 & 16.5 \\
\hline S5 & Landslide-crown area & 10.8 & 75.2 & 14.1 \\
\hline S6 & Landslide-head zone & 9.5 & 69.8 & 20.7 \\
\hline S7 & Landslide-body & 9.2 & 68.1 & 22.7 \\
\hline
\end{tabular}

To approach the $\mathrm{Na}^{+}$and $\mathrm{SO}_{4}{ }^{2-}$ content levels from leaching, the thenardite and natron specific surfaces $\left(S p_{m}\right)$ had to be increased to $120 \%$ and $150 \%$, respectively, in comparison to that calculated using formula 4 . For the other considered ions (reported in Supplementary Materials), $\mathrm{Mg}^{2+}$ and $\mathrm{K}^{+}$were almost absent both in estimated and observed leaching (for both cations, contents were lower than $0.05 \mathrm{mg} \mathrm{L}^{-1}$ ), while $\mathrm{Cl}^{-}$was nil in simulation due to the lack of mineralogical phases containing chloride (observed $\mathrm{Cl}^{-}$ was about $0.20 \mathrm{mg} \mathrm{L}^{-1}$ ).

Moreover, $S p_{m}$ of calcite was reduced to $70 \%$ in order to bring the estimated calcium contents closer to those observed in leaching $\left(\mathrm{Ca}^{2+}=0.22 \mathrm{mg} \mathrm{L}^{-1}\right)$.

Table 3. Mineralogical composition of the seven samples (S1, S2, S3, S4, S5, S6, and S7) as obtained from quantitative analyses. Phases are reported as \% in weight.

\begin{tabular}{ccccccccc}
\hline Mineral Phase & Molecular Formula & $\mathbf{S 1}(\mathbf{\%})$ & $\mathbf{S 2 ~ ( \% )}$ & $\mathbf{S 3}$ (\%) & $\mathbf{S 4}$ (\%) & $\begin{array}{c}\text { S5 } \\
\text { (\%) }\end{array}$ & $\begin{array}{c}\text { S6 } \\
\text { (\%) }\end{array}$ & S7 (\%) \\
\hline quarz & $\mathrm{SiO}_{2}$ & 51.6 & 47.5 & 38.0 & 49.4 & 44.5 & 47.2 & 50.6 \\
\hline K-feldspar & $\mathrm{KAlSi}_{3} \mathrm{O}_{8}$ & 2.7 & 1.7 & 0.4 & 0.6 & 3.4 & 11.6 & 0.7 \\
\hline albite & $\mathrm{NaAlSi}_{3} \mathrm{O}_{8}$ & 5.6 & 6.1 & 0.6 & 5.7 & 11.4 & 0.0 & 3.4 \\
\hline $\begin{array}{c}\text { smectite } \\
\text { (Ca-montmorillonite) }\end{array}$ & $\mathrm{Ca}_{0.165} \mathrm{Al}_{2.33} \mathrm{Si}_{3.67} \mathrm{O}_{10}(\mathrm{OH})_{2}$ & 0.5 & 0.0 & 23.8 & 0.0 & 0.1 & 0.0 & 0.3 \\
\hline chlorite & $\mathrm{Mg}_{5} \mathrm{Al}_{2} \mathrm{Si}_{3} \mathrm{O}_{10}(\mathrm{OH})_{8}$ & 13.5 & 16.3 & 7.2 & 14.7 & 16.7 & 10.6 & 15.4 \\
\hline illite & $\mathrm{K}_{0.6} \mathrm{Mg}_{0.25} \mathrm{Al}_{2.3} \mathrm{Si}_{3.5} \mathrm{O}_{10}(\mathrm{OH})_{2}$ & 20.0 & 24.2 & 5.5 & 22.0 & 16.4 & 12.0 & 21.3 \\
\hline calcite & $\mathrm{CaCO}_{3}$ & 6.1 & 4.2 & 6.3 & 7.6 & 8.0 & 18.6 & 8.3 \\
\hline kaolinite & $\mathrm{K}_{0.6} \mathrm{Mg}_{0.25} \mathrm{Al}_{2.3} \mathrm{Si}_{3.5} \mathrm{O}_{10}(\mathrm{OH})_{2}$ & 0.0 & 0.0 & 18.2 & 0.0 & 0.0 & 0.0 & 0.0 \\
\hline
\end{tabular}

In this way, simulated $\mathrm{HCO}_{3}{ }^{-}$results were the ones that were furthest away from the data observed in leaching (Figure 6). Discrepancies were more evident in the time window 
$5 \mathrm{~min}$ to $1 \mathrm{~h}$ and progressively decreased to the end of the leaching test, when observed and simulated values at $10 \mathrm{~h}$ almost corresponded. The higher values observed in leaching were probably due to the $\mathrm{CO}_{2}$ rebalancing phenomena between the gas and liquid phase on the surface of the water, moved by the stirrer.

Table 4. Mineralogical assemblage of the kinetic modelling between pore water and soil sample S5 performed with the software PHREEQC. Kinetic data $\left(K_{m}{ }^{H}, K_{m}{ }^{H 20}, K_{m}{ }^{\mathrm{OH}}\right)$ were obtained by calibration.

\begin{tabular}{|c|c|c|c|c|c|c|c|}
\hline \multirow[b]{2}{*}{$\begin{array}{l}\text { Mineral } \\
\text { Phase }\end{array}$} & \multirow[b]{2}{*}{ Moles } & \multirow{2}{*}{$\begin{array}{c}\text { Specific } \\
\text { Surface } \\
\left(\mathrm{m}^{-2}\right)\end{array}$} & \multirow[b]{2}{*}{ Chemical Reaction } & \multicolumn{2}{|c|}{ Thermodinamic } & \multicolumn{2}{|l|}{ Kinetic } \\
\hline & & & & $\log K$ & $\begin{array}{c}K_{m}^{H} \\
\left(\mathrm{~mol} \mathrm{~m}^{-2} \mathrm{~s}^{-1}\right)\end{array}$ & $\begin{array}{c}K_{m}{ }^{\mathrm{H} 2 \mathrm{O}} \\
\left(\mathrm{mol} \mathrm{\textrm {m } ^ { - 2 }} \mathrm{s}^{-1}\right)\end{array}$ & $\begin{array}{c}K_{m} \mathrm{OH} \\
\left(\mathrm{mol} \mathrm{m}^{-2} \mathrm{~s}^{-1}\right)\end{array}$ \\
\hline quartz & 53.5325 & 600.04 & $\mathrm{SiO}_{2}+\mathrm{H}_{2} \mathrm{O}=\mathrm{H}_{4} \mathrm{SiO}_{4}$ & -2.72 & $1.02 \times 10^{-14}$ & $1.02 \times 10^{-14}$ & $5.12 \times 10^{-17}$ \\
\hline $\begin{array}{l}\text { K- } \\
\text { feldspar }\end{array}$ & 0.6046 & 32.49 & $\begin{array}{l}\mathrm{KAlSi}_{3} \mathrm{O}_{8}: 3 \mathrm{H}_{2} \mathrm{O}+4 \mathrm{H}^{+}+\mathrm{H}_{2} \mathrm{O} \\
\quad=\mathrm{Al}^{3+}+\mathrm{K}^{+}+3 \mathrm{H}_{4} \mathrm{SiO}_{4}\end{array}$ & 0.04 & $8.70 \times 10^{-11}$ & $3.79 \times 10^{-13}$ & $6.31 \times 10^{-22}$ \\
\hline albite & 1.330872765 & 66.61 & $\begin{array}{c}\mathrm{NaAlSi}_{3} \mathrm{O}_{8}+4 \mathrm{H}^{+}+4 \mathrm{H}_{2} \mathrm{O}= \\
\mathrm{Al}^{3+}+\mathrm{Na}^{+}+3 \mathrm{H}_{4} \mathrm{SiO}_{4}\end{array}$ & 2.74 & $6.92 \times 10^{-11}$ & $2.75 \times 10^{-13}$ & $2.51 \times 10^{-16}$ \\
\hline smectite & 0.0849 & 2493.21 & $\begin{array}{c}\mathrm{Ca}_{0.3} \mathrm{Mg}_{0.6} \mathrm{Al}_{1.4} \mathrm{Si}_{4} \mathrm{O}_{10}(\mathrm{OH})_{2}+ \\
6 \mathrm{H}^{+}+4 \mathrm{H}_{2} \mathrm{O}=1.4 \mathrm{Al}^{3+}+ \\
0.3 \mathrm{Ca}^{2+}+0.6 \mathrm{Mg}^{2+}+4 \mathrm{H}_{4} \mathrm{SiO}_{4}\end{array}$ & 8.94 & $1.05 \times 10^{-11}$ & $1.66 \times 10^{-13}$ & $3.02 \times 10^{-17}$ \\
\hline chlorite & 1.3758 & $84,145.50$ & $\begin{array}{c}\mathrm{Mg}_{5} \mathrm{Al}_{2} \mathrm{Si}_{3} \mathrm{O}_{10}(\mathrm{OH})_{8}+16 \mathrm{H}^{+}= \\
2 \mathrm{Al}^{3+}+5 \mathrm{Mg}^{2+}+3 \mathrm{H}_{4} \mathrm{SiO}_{4}+ \\
6 \mathrm{H}_{2} \mathrm{O}\end{array}$ & 61.72 & $7.76 \times 10^{-12}$ & $2.95 \times 10^{-13}$ & $4.57 \times 10^{-14}$ \\
\hline illite & 3.2464 & $124,660.78$ & $\begin{array}{c}\mathrm{K}_{0.85} \mathrm{Mg}_{0.25} \mathrm{Al}_{2.35} \mathrm{Si}_{3.4} \mathrm{O}_{10}(\mathrm{OH})_{2} \\
+8.4 \mathrm{H}^{+}+1.6 \mathrm{H}_{2} \mathrm{O}=2.35 \mathrm{Al}^{3+}+ \\
0.85 \mathrm{~K}^{+}+0.25 \mathrm{Mg}^{2+}+ \\
3.4 \mathrm{H}_{4} \mathrm{SiO}_{4}\end{array}$ & 9.72 & $1.41 \times 10^{-12}$ & $2.81 \times 10^{-14}$ & $2.81 \times 10^{-15}$ \\
\hline calcite & 3.9988 & 0.72 & $\mathrm{CaCO}_{3}+\mathrm{H}^{+}=\mathrm{HCO}^{3-}+\mathrm{Ca}^{2+}$ & 1.84 & $5.01 \times 10^{-1}$ & $1.55 \times 10^{-6}$ & $3.31 \times 10^{-4}$ \\
\hline thenardite & 0.0542 & 34.21 & $\mathrm{Na}_{2} \mathrm{SO}_{4}=2 \mathrm{Na}^{+}+\mathrm{SO}_{4}^{2-}$ & -0.34 & $2.05 \times 10$ & $3.48 \times 10^{-6}$ & $5.24 \times 10^{-9}$ \\
\hline natron & 0.1209202 & 77.43 & $\begin{array}{c}\mathrm{Na}_{2} \mathrm{CO}_{3} 7 \mathrm{H}_{2} \mathrm{O}+\mathrm{H}^{+}=\mathrm{HCO}^{3-} \\
+2 \mathrm{Na}^{+}+7 \mathrm{H}_{2} \mathrm{O}\end{array}$ & 9.51 & $4.14 \times 1$ & $7.17 \times 10^{-3}$ & $4.34 \times 10^{-5}$ \\
\hline
\end{tabular}

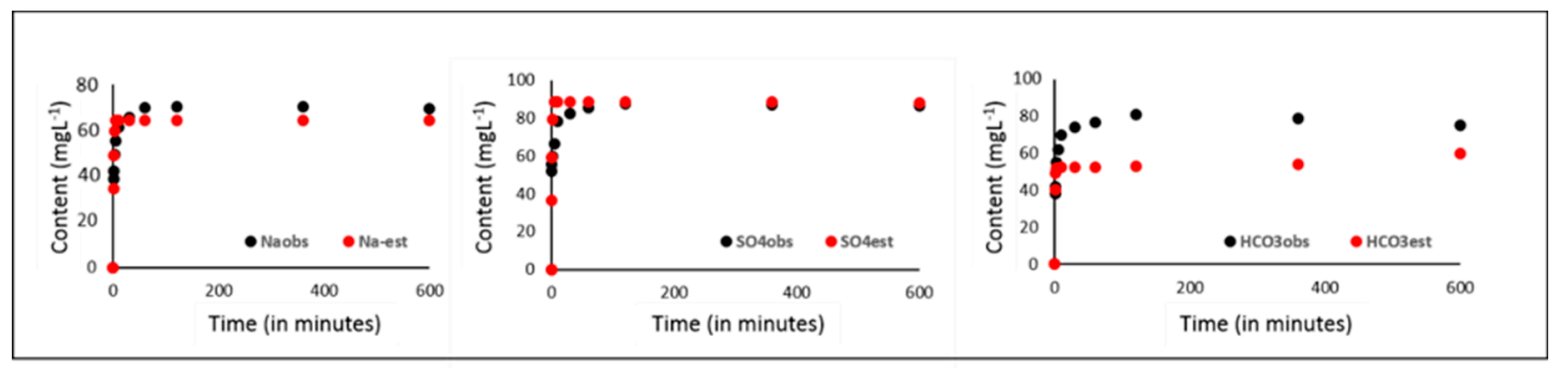

Figure 6. Chemical composition $\left(\mathrm{Na}^{+}, \mathrm{SO}_{4}{ }^{2-}\right.$ and $\left.\mathrm{HCO}_{3}{ }^{-}\right)$of leached water (observed water: black dots) compared with the results of the bets calibration of the kinetic model (estimated water: red dots).

After the calibration, the kinetic model was applied at the field scale by considering an aqueous solution (rainwater with chemical composition equal to that reported in [28] in a locality close to the study site, with a mean temperature equal to the mean annual air temperature of Vedriano, i.e., $13{ }^{\circ} \mathrm{C}$ and $\mathrm{pH}=5.8$ ) interacting with the mineralogical assemblage of S5. The amount of each reactant was calculated as moles interacting with water through pores, i.e., the porosity of the materials. The latter has been estimated to be equal to $25 \%$ by considering the grain size distribution. Clayey minerals such as smectite, illite and chlorite have characteristic specific surfaces as reported in [25] (i.e., 80, 100 and $100 \mathrm{~m}^{2} \mathrm{~g}^{-1}$, respectively). As in the abovementioned case of leaching water, groundwater was also allowed to exchange $\mathrm{O}_{2}$ and $\mathrm{CO}_{2}$ with the atmosphere. This assumption means 
that $\mathrm{CO}_{2}$ and $\mathrm{O}_{2}$ diffuse to the groundwater due to open fractures and pores, providing the necessary acid for the neutralization of the base generated through the dissolution of clay minerals. Furthermore, no secondary phase precipitations were allowed. Moreover, a 1 day calculation time step was selected.

Results indicated a quick and progressive dissolution of natron and thenardite; both mineralogical phases already started to be dissolved at the first step of dissolution (after 1 day of interaction, the estimated content of $\mathrm{SO}_{4}{ }^{2-}$ was already similar to that observed in spring S2, i.e., $1460 \mathrm{mgl}^{-1}$ while $\mathrm{Na}^{+}$and $\mathrm{HCO}_{3}{ }^{-}$were equal to 750 and $145 \mathrm{mg} \mathrm{L}^{-1}$, respectively). After 130 days of interactions, estimated pore-water interaction reached the maximum content of $\mathrm{Na}^{+}, \mathrm{SO}_{4}{ }^{2-}$ and $\mathrm{HCO}_{3}{ }^{-}$observed in $\mathrm{S} 2$ (equal to 960, 1430 and $1060 \mathrm{mg} \mathrm{L}^{-1}$, respectively).

Regarding the other ions, at 130 days of interactions, the content of $\mathrm{Cl}^{-}$was the same as that of rainfall $\left(1.4 \mathrm{mg} \mathrm{L}^{-1}\right.$, as already anticipated for the leaching tests; no other phases containing chloride were available in the mineralogical bulk), while the estimated $\mathrm{Mg}^{2+}\left(2 \mathrm{mg} \mathrm{L}^{-1}\right)$ was remarkably lower than that observed in the Vedriano landslide (about $50 \mathrm{mg} \mathrm{L}^{-1}$ in S2). Similarly, the estimated content of $\mathrm{K}^{+}$was lower than the observed value (estimated content of $\mathrm{K}^{+}$on the order of $1 \mathrm{mg} \mathrm{L}^{-1}$ instead of $3 \mathrm{mg} \mathrm{L}^{-1}$ observed in water from S2). The estimated $\mathrm{Ca}^{2+}$ content $\left(9 \mathrm{~g} \mathrm{~L}^{-1}\right)$ was also lower than the corresponding maximum values detected in the Vedriano landslide $\left(48 \mathrm{mg} \mathrm{L}^{-1}\right)$.

\section{Discussion}

Results of leaching data allowed us to verify that the samples taken from two specific outcrops in the vicinity of the Mt. Staffola (S3 and S4) showed a much higher mineralization (EC slightly above $100 \mu \mathrm{s} \mathrm{cm}^{-1}$ ) than that characterising leaching of the same geological formation (MSF3b and MSF3a) samples collected far away (L3 and L4; with values of EC of 40 and $80 \mu \mathrm{s} \mathrm{cm}^{-1}$, respectively). These high EC values were found to be even higher in the sample S5 (i.e., that located in the earthslide and which originated from the dismembering of the geological formations MSF3b and MSF3a in the crown area of the landslide; the EC value was $280 \mu \mathrm{s} \mathrm{cm}^{-1}$ ). Lixiviation from the other two geological formations outcropping the area (MSF2 and MSF3) were not characterised by high EC enrichment, even near the landslide zone (EC lower than $80 \mu \mathrm{sm}^{-1}$ ). The highest values of $\mathrm{EC}$ were linked to $\mathrm{Na}-\mathrm{SO}_{4}-\mathrm{HCO}_{3}$ mineralogical components, which were not identified by the mineralogical analyses carried out on the samples. A specific mineralogical analysis carried out on the white powder found in the vicinity of sample $\mathrm{S} 5$ allowed us to identify that they were composed of thenardite $\left(\mathrm{Na}_{2} \mathrm{SO}_{4}\right)$ and natron $\left(\mathrm{NaCO}_{3} 7 \mathrm{H}_{2} \mathrm{O}\right)$. The results of chemical analysis carried out at the end of the leaching (10h) on soil water and soil sample S5 allowed us to quantify the amount of natron and thenardite was about 0.28 and $0.06 \mathrm{~g}$ per $50 \mathrm{~g}$ of dried sample, respectively, and to perform a final kinetic model simulating the interaction between soils composing the earthslide (S5) and rainfall, i.e., the hydrochemical processes occurring at the slope scale (see Figure 7).

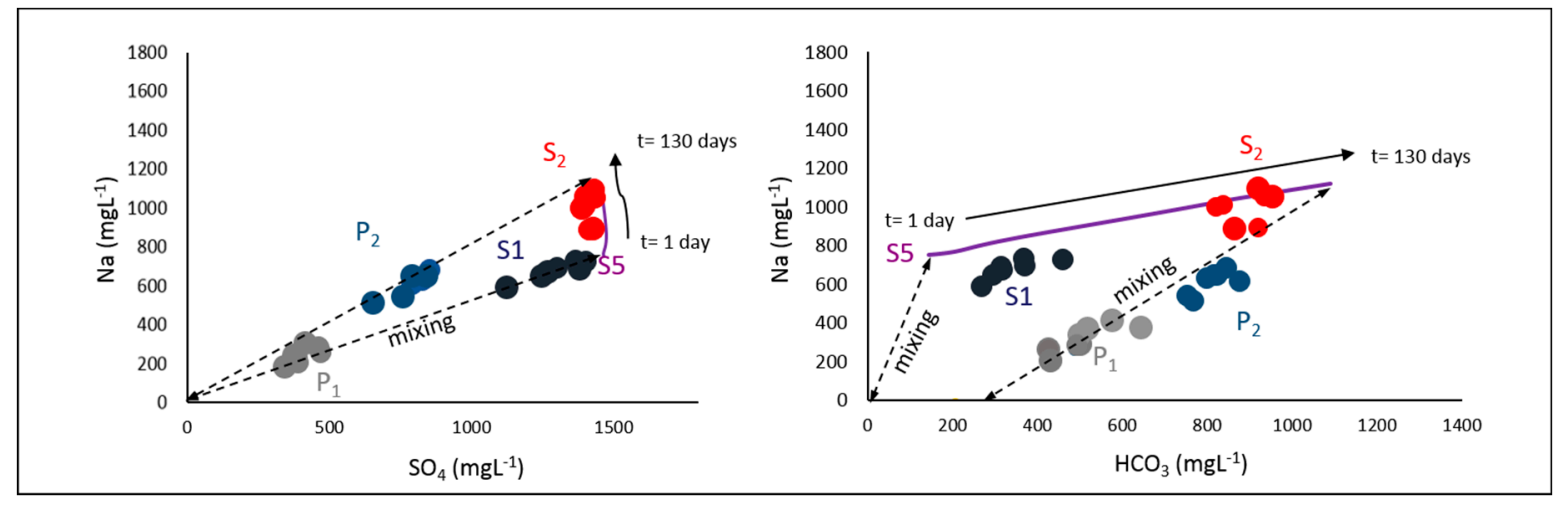

Figure 7. $\mathrm{Na}-\mathrm{SO}_{4}$ (on the left) and $\mathrm{Na}-\mathrm{HCO}_{3}$ (on the right) results of the kinetic modelling (purple dots) for interaction between rainwater and the soil sample S5, compared with groundwater monitoring P1, P2, S1 and S2. 
Raindrops reaching the ground during the first phases of a meteorological event interact with soils localized in the earthslide area (i.e., samples S5) by already assuming the final sulphate content of the most mineralized groundwater hosted in the landslide (that of springs S1 and S2). This means that thenardite dissolution was interrupted after the first step. The further interactions highlight a progressive enrichment of sodium $\left(\mathrm{Na}^{+}\right)$and bicarbonates $\left(\mathrm{HCO}_{3}{ }^{-}\right)$that is due to the progressive dissolution of natron; after 130 days of interaction, mineralization of simulated water reached that of the samples belonging to spring S2 (Figure 7).

By looking at the hydrogeological processes occurring at the slope scale (see Figure 8), we can reasonably hypothesize that groundwater discharging from springs (S1 and S2) located in the earthslide is the result of the localized groundwater flow-path developing over a reduced time-period (maximum 130 days). The latter are recharged by meteoric water infiltrated in the area, characterised by the widespread presence of natron and thenardite. The other groundwater monitoring points (i.e., piezometers) are fed by less mineralized groundwater than the aforementioned ones (S1 and S2). Groundwater collected from P1 (here we recall that this groundwater sampling point is located in the crown area of the earthslide, upward of S1 and S2) showed the lowest values of $\mathrm{Na}^{+}, \mathrm{HCO}_{3}{ }^{-}$and $\mathrm{SO}_{4}{ }^{2-}$ while P2 (the area near the transition between the earthslide and earthflow1) showed a remarkable increase in all the considered ions which lie on the mixing lines between rainfall and groundwater from springs (S1 and S2). That led us to suppose that meteoric recharge infiltrated through fissures and fractures in the earthslide area moves towards the main sliding surface; there, this $\mathrm{Na}-\mathrm{SO}_{4}-\mathrm{HCO}_{3}$ enriched water mix with less mineralized groundwater was fed by the meteoric recharge from the crown area (P1).

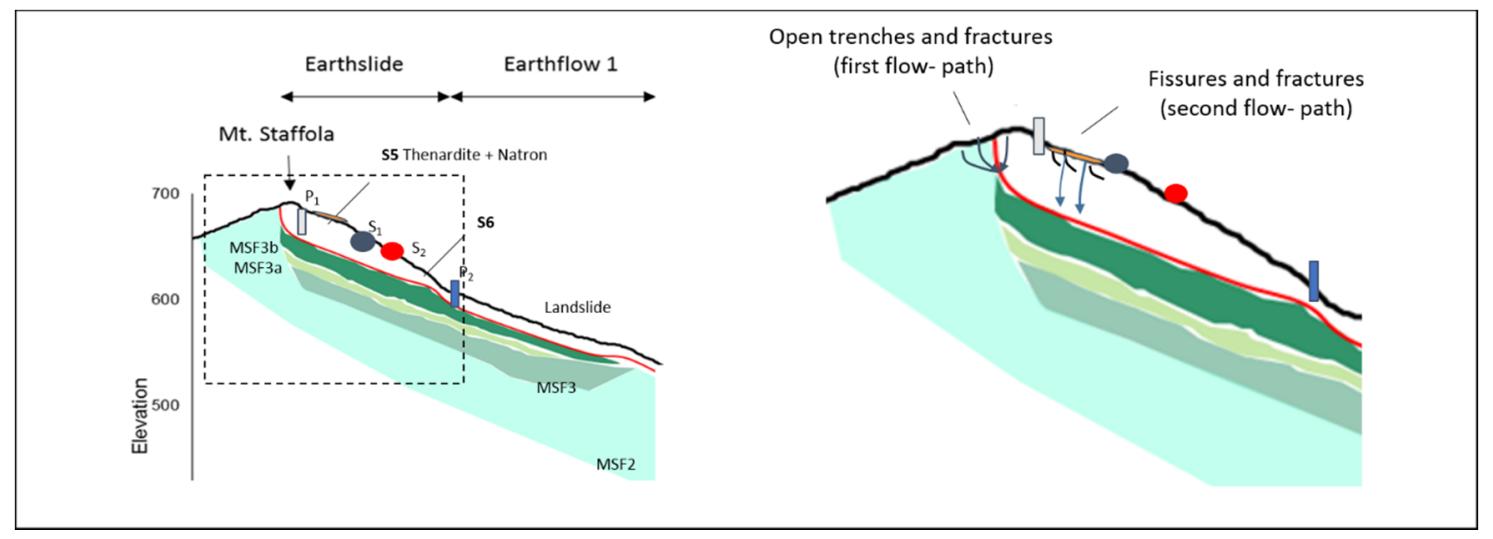

Figure 8. Sketch of the source zone in which the first and second flow-paths (in blue) connected to the main slip surface (in red) were reported.

These results suggest that, for the investigated sector of the Vedriano landslide (i.e., the earthslide), groundwater moves through two main flow-paths (Figure 8). The first flow-path involves less mineralized water flowing through the main sliding surface of the earthslide and is recharged near the Mt. Staffola peak. The second is characterised by much more mineralized water (enriched in $\mathrm{Na}, \mathrm{HCO}_{3}$ and $\mathrm{SO}_{4}$ ) that assume such chemical signature by percolating from the surface, where the meteoric water interact with soils rich of thenardite and natron. This second flow-path then conveyed the highly mineralized water to the sliding surface and finally discharges a mixing of the two waters near P2, where the earthslide evolves into the earthflow1. As highlighted by the kinetic model, such hydrological processes should take place in less than a year.

It is evident that the information gained by this study can be useful for the appraisal of countermeasure works aimed at reducing the landslide risk. The latter should focus on rapid removal of meteoric and surface waters from the areas in which trenches and open cracks allow recharge water to be conveyed quickly to the main soil slip surface. As highlighted by the study, such areas are located in the vicinity of the Mt. Staffola 
peak (recharge zone of the first flow-path) and in the reduced sector of the earthslide in which thenardite and natron are widespread (recharge zone of the second flow-path). There, the development of drain pipes along with an adequate channeling of the surface waters could reduce the development of quick rises in pore pressures and subsequent potential reactivation of the earthslide.

Despite the presented results allowing a gain of insight into the hydrological processes occurring into the source area of the Vedriano landslide, further efforts should be spent to implement the kinetic model. Amongst others, further in-situ investigations (such as slug-tests and pumping tests in order to assess permeability and effective porosities of the earthslide materials) are required to constrain the input parameters of the kinetic model. Moreover, further kinetic simulations should consider in more detail the behaviour of $\mathrm{K}^{+}$, $\mathrm{Mg}^{2+}, \mathrm{Ca}^{2+}$, by also accounting for the redox conditions and activity diagrams of some specific secondary mineralogical phases and their consequent saturation/precipitation.

\section{Conclusions}

This study demonstrated the usefulness of a comprehensive hydrochemical investigation involving both common groundwater chemical analyses (main anions and cations), leaching tests of soils, mineralogical analyses and geochemical modelling to unravel the hydrogeological processes occurring within complex media such as clay-rich slopes such as those from the northern Italian Apennines. Here, the presence of different mineralogical bulks (linked to several geological formations that are often superimposed) may enhance the specific geochemical signatures of water flow-paths within the slopes which in turn, in the case of landsliding, are responsible for the pore pressures acting on the slip surfaces. Firstly, the importance to also consider the solid matrix hosting the groundwater (by means of leaching tests and mineralogical analysis) to constrain the flow-paths at the slope scale has been stressed. This is an important task that has allowed us to understand that an important recharge quota is provided also by infiltrative water directly from the top of the earthslide (in which meteoric water acquires a peculiar geochemical signature due to the dissolution of specific Na-rich minerals). Secondly, it has been highlighted that kinetic modelling is suitable for representing hydrochemical processes such as those occurring at the hillslope scale if properly calibrated on leaching tests and mineralogical analyses. In the proposed case study (earthslide), kinetic models provided indications for depicting groundwater mixing processes occurring below the ground surface, allowing us to roughly estimate the residence time required by water molecules to assume the highest mineralization.

The abovementioned outcomes can help authorities in charge of landslide management as they make countermeasures more effective in reducing pore water pressures acting on the soil slip surface.

Supplementary Materials: The following are available online at https:/ /www.mdpi.com/2076-326 3/11/1/1/s1. Leaching tests (Electrical Conductivity EC), Leaching tests (Chemistry), Groundwater (Chemistry), Rainwater (Chemistry, from [28]), Kinetic model results (estimated chemistry after interaction between $\mathrm{S} 5$ and rainwater).

Author Contributions: Conceptualization, F.C.; methodology, F.C.; formal analysis, F.C.; writingoriginal draft preparation, F.C.; writing-review and editing, F.C. and A.T. All authors have read and agreed to the published version of the manuscript.

Funding: This research received no external funding.

Acknowledgments: F.C. wishes to dedicate this manuscript to the memory of C. Gorgoni (University of Modena, Italy). Thank you, Professor for having introduced me to the use of geochemical tracers in hillslope hydrology and for sharing your passion for geochemistry with me and other BSc and $\mathrm{PhD}$ students. The authors warmly thank two anonymous reviewers for their useful advice on the early draft of the manuscript.

Conflicts of Interest: The authors declare no conflict of interest. 


\section{References}

1. Jenkins, A.; Ferrier, R.C.; Harriman, R.; Ogunkoya, Y.O. A case study in catchment hydrochemistry: Conflicting interpretations from hydrological and chemical observations. Hydrol. Process. 1994, 8, 335-349. [CrossRef]

2. Burns, D.A.; McDonnell, J.J.; Hooper, R.P.; Peters, N.E.; Freer, J.; Kendall, C.; Beven, K. Quantifying contributions to storm runoff through end-member mixing analysis and hydrologic measurements at the Panola Mountain Research Watershed (Georgia, USA). Hydrol. Process. 2001, 15, 1903-1924. [CrossRef]

3. Bogaard, T.; Guglielmi, Y.; Marc, V.; Emblanch, C.; Bertrand, C.; Mudry, J. Hydrogeochemistry in landslide research: A review. Bull. Soc. Géol. Fr. 2007, 178, 113-126. [CrossRef]

4. De Montety, V.; Marc, V.; Emblach, C.; Malet, J.-P.; Bertrand, C.; Maquaire, O.; Bogaard, T. Identifying origin of groundwater and flow processes in complex landslides affecting black marls in southern French Alps: Insights from an hydrochemical survey. Earth Surf. Proc. Landf. 2007, 32, 32-48. [CrossRef]

5. Bogaard, T.; Buma, J.; Klawer, C. Testing the potential of geochemical techniques for identifying hydrological systems within landslides in partly weathered marls. Geomorphology 2004, 58, 323-338. [CrossRef]

6. Guglielmi, Y.; Vengeon, J.; Bertrand, C.; Mudry, J.; Follacci, J.; Giraud, A. Hydrogeochemistry: An investigation tool to evaluate infiltration into large moving rock masses (case study of La Clapière and Séchilienne alpine landslides). Bull. Int. Assoc. Eng. Geol. 2002, 61, 311-324. [CrossRef]

7. Binet, S.; Spadini, L.; Bertrand, C.; Guglielmi, Y.; Mudry, J.; Scavia, C. Variability of the groundwater sulfate concentration in fractured rock slopes: A tool to identify active unstable areas. Hydrol. Earth Syst. Sci. 2009, 13, 2315-2327. [CrossRef]

8. Guglielmi, Y.; Bertrand, C.; Compagnon, F.; Follacci, J.; Mudry, J. Acquisition of water chemistry in a mobile fissured basement massif: Its role in the hydrogeological knowledge of the La Clapière landslide (Mercantour massif, southern Alps, France). J. Hydrol. 2000, 229, 138-148. [CrossRef]

9. Deiana, M.; Cervi, F.; Pennisi, M.; Mussi, M.; Bertrand, C.; Tazioli, A.; Corsini, A.; Ronchetti, F. Chemical and isotopic investigations $(\delta 18 \mathrm{O}, \delta 2 \mathrm{H}, 3 \mathrm{H}, 87 \mathrm{Sr} / 86 \mathrm{Sr})$ to define groundwater processes occurring in a deep-seated landslide in flysch. Hydrogeol. J. 2018, 26, 2669-2691. [CrossRef]

10. Cervi, F.; Ronchetti, F.; Martinelli, G.; Bogaard, T.A.; Corsini, A. Origin and assessment of deep groundwater inflow in the Ca' Lita landslide using hydrochemistry and in situ monitoring. Hydrol. Earth Syst. Sci. 2012, 16, 4205-4221. [CrossRef]

11. Marc, V.; Bertrand, C.; Malet, J.-P.; Carry, N.; Simler, R.; Cervi, F. Groundwater-Surface waters interactions at slope and catchment scales: Implications for landsliding in clay-rich slopes. Hydrol. Process. 2016, 31, 364-381. [CrossRef]

12. Krzeminska, D.M.; Bogaard, T.A.; Debieche, T.-H.; Cervi, F.; Marc, V.; Malet, J.-P. Field investigation of preferential fissure flow paths with hydrochemical analysis of small-scale sprinkling experiments. Earth Surf. Dyn. 2014, 2, 181-195. [CrossRef]

13. Shao, W.; Bogaard, T.; Bakker, M.; Berti, M. The influence of preferential flow on pressure propagation and landslide triggering of the Rocca Pitigliana landslide. J. Hydrol. 2016, 543, 360-372. [CrossRef]

14. Bogaard, T.; Greco, R. Landslide hydrology: From hydrology to pore pressure. Wiley Interdiscip. Rev. Water 2015, 3, 439-459. [CrossRef]

15. Cervi, F.; Nistor, M.-M. High Resolution of Water Availability for Emilia-Romagna Region over 1961-2015. Adv. Meteorol. 2018, 2018, 1-13. [CrossRef]

16. Bertolini, G.; Gorgoni, C. La lavina di Roncovetro (Vedriano, Comune di Canossa, Provincia di Reggio Emilia). Quad. Geol. Appl. 2001, 8, 1-21. (In Italian)

17. Mucchi, L.; Jayousi, S.; Martinelli, A.; Caputo, S.; Intrieri, E.; Gigli, G.; Gracchi, T.; Mugnai, F.; Favalli, M.; Fornaciai, A.; et al. A Flexible Wireless Sensor Network Based on Ultra-Wide Band Technology for Ground Instability Monitoring. Sensors 2018, 18, 2948.

18. Vannucchi, P.; Bettelli, G. Myths and recent progress regarding the Argille Scagliose, Northern Apennines, Italy. Int. Geol. Rev. 2010, 52, 1106-1137. [CrossRef]

19. Gran, G. Determination of the equivalence point in potentiometric titrations. Part II. Analyst 1952, 77, 661-671. [CrossRef]

20. USGS. A Simple Field Leach Test to Assess Potential Leaching of Soluble Constituents from Mine Wastes, Soils, and Other Geologic Materials; USGS Fact Sheet: Denver, CO, USA, 2005; pp. 2005-3100.

21. Rietveld, H.M. A profile refinement method for nuclear and magnetic structures. J. Appl. Crystallogr. 1969, 2, 65-71. [CrossRef]

22. Parkhurst, D.L.; Appelo, C.A.J. PHREEQC User's Manual Program, Water-Resources Investigations Report; US Geological Survey: Denver, CO, USA, 2004.

23. Lasaga, A.C. Chemical kinetics of water-rock interactions. J. Geophys. Res. Space Phys. 1984, 89, 4009-4025. [CrossRef]

24. Freeze, R.A.; Cherry, J.A. Groundwater; Prentice-Hall International: Englewood Cliffs, NJ, USA, 1979.

25. Santamarina, J.C.; Klein, K.A.; Wang, Y.H.; Prencke, E. Specific surface: Determination and relevance. Can. Geotech. J. 2002, 39, 233-241.

26. Palandri, J.L.; Kharaka, Y.K. A compilation of rate parameters of water-mineral interaction kinetics for application to geochemical modeling. Open-File Rep. 2004. [CrossRef]

27. Marty, N.C.; Claret, F.; Lassin, A.; Tremosa, J.; Blanc, P.; Madé, B.; Giffaut, E.; Cochepin, B.; Tournassat, C. A database of dissolution and precipitation rates for clay-rocks minerals. Appl. Geochem. 2015, 55, 108-118. [CrossRef]

28. Panettiere, P.; Cortecci, G.; Dinelli, E.; Bencini, A.; Guidi, M. Chemistry and sulfur isotopic composition of precipitation at Bologna. Italy. Appl. Geochem. 2000, 15, 1455-1467. [CrossRef] 